\title{
LMTK3 Deficiency Causes Pronounced Locomotor Hyperactivity and Impairs Endocytic Trafficking
}

\author{
Takeshi Inoue, ${ }^{1}$ Naosuke Hoshina, ${ }^{1,5}$ Takanobu Nakazawa, ${ }^{1}$ Yuji Kiyama, ${ }^{2}$ Shizuka Kobayashi, ${ }^{2}$ Takaya Abe, ${ }^{3}$ \\ Toshifumi Yamamoto, ${ }^{4}$ Toshiya Manabe, ${ }^{2}$ and Tadashi Yamamoto ${ }^{1,5}$ \\ ${ }^{1}$ Division of Oncology and 2Division of Neuronal Network, Institute of Medical Science, University of Tokyo, Minato-ku, Tokyo 108-8639, Japan, \\ ${ }^{3}$ Laboratory for Animal Resources and Genetic Engineering, RIKEN Center for Developmental Biology, Kobe 650-0047, Japan, ${ }^{4}$ Laboratory of Molecular \\ Recognition, Graduate School of Arts and Sciences, Yokohama City University, Yokohama 236-0027, Japan, and ${ }^{5}$ Cell Signal Unit, Okinawa Institute of \\ Science and Technology, Onna-son, Okinawa 904-0495, Japan
}

LMTK3 belongs to the LMTK family of protein kinases that are predominantly expressed in the brain. Physiological functions of LMTK3 and other members of the LMTK family in the CNS remain unknown. In this study, we performed a battery of behavioral analyses using Lmtk $3^{-I-}$ mice and showed that these mice exhibit abnormal behaviors, including pronounced locomotor hyperactivity, reduced anxiety behavior, and decreased depression-like behavior. Concurrently, the dopamine metabolite levels and dopamine turnover rate are increased in the striata of $L m t k 3^{-1-}$ mice compared with wild-type controls. In addition, using cultured primary neurons from Lmtk $3^{-1-}$ mice, we found that LMTK3 is involved in the endocytic trafficking of $N$-methyl-D-aspartate receptors, a type of ionotropic glutamate receptor. Altered membrane traffic of the receptor in $L m t k 3^{-1-}$ neurons may underlie behavioral abnormalities in the mutant animals. Together, our data suggest that LMTK3 plays an important role in regulating locomotor behavior in mice.

Key words: endocytosis; hyperactivity; LMTK; locomotor; membrane trafficking

\section{Introduction}

Lemur tyrosine kinases (LMTKs), also called lemur kinases or apoptosis-associated tyrosine kinases, form a family of serine/ threonine (Ser/Thr) protein kinases that are predominantly expressed in the CNS (Kawa et al., 2004; Tomomura et al., 2007). Members of this kinase family, LMTK1-3, comprise an N-terminal transmembrane region, a kinase domain, and a long C-terminal tail region (Tomomura et al., 2007). We and another group have reported that LMTK2 interacts with a motor protein, myosin VI, and is involved in regulation of endosomal membrane trafficking in cultured cell lines (Chibalina et al., 2007; Inoue et al., 2008). LMTK1 also regulates formation of the endocytic regulatory compartment (Takano et al., 2010), suggesting

Received April 17, 2013; revised March 2, 2014; accepted March 19, 2014.

Author contributions: T.I., T.M., and Tadashi Yamamoto designed research; T.I., N.H., Y.K., S.K., T.A., and Toshifumi Yamamoto performed research; T.I., N.H., T.N., Y.K., S.K., Toshifumi Yamamoto, T.M., and Tadashi Yamamoto analyzed data; T.I. and Tadashi Yamamoto wrote the paper.

This work was supported by the Strategic Research Program for Brain Sciences and the Grant-in-Aid for Scientific Research from the Ministry of Education, Culture, Sports, Science, and Technology of Japan. We thank M. Tomomura (Meikai University School of Dentistry) for mouse Lmtk3 CDNA and anti-mouse LMTK3 antibody and S. D. Aird for critical reading of the manuscript.

The authors declare no competing financial interests.

Correspondence should be addressed to either of the following: Dr. Toshiya Manabe, Division of Neuronal Network, Institute of Medical Science, University of Tokyo, Minato-ku, Tokyo 108-8639, Japan, E-mail: tmanabetky@umin.ac.jp; or Dr. Tadashi Yamamoto, Cell Signal Unit, Okinawa Institute of Science and Technology, Onna-son, Okinawa 904-0495, Japan, E-mail: tyamamot@ims.u-tokyo.ac.jp.

T. Inoue's present address: Laboratory of Lymphocyte Differentiation, WPI Immunology Frontier Research Center, Osaka University, Suita, Osaka 565-0871, Japan.

T. Nakazawa's present address: iPS Cell-based Research Project on Brain Neuropharmacology and Toxicology, Graduate School of Pharmaceutical Sciences, Osaka University, Suita, Osaka 565-0871, Japan.

DOI:10.1523/JNEUROSCI.1621-13.2014

Copyright $\odot 2014$ the authors $\quad 0270-6474 / 14 / 345927-11 \$ 15.00 / 0$ that control of membrane traffic is a common function of this family of kinases. Although we have reported that Lmtk2deficient mice are infertile and that LMTK2 is essential for the late stages of spermatogenesis (Kawa et al., 2006), it is not clear how endocytic events are relevant to spermatogenesis. We do not know either the physiological functions of LMTK2 kinase in the CNS.

Another member of the LMTK kinase family, LMTK3, is highly expressed in cerebral cortex, cerebellum, and hippocampus (Tomomura et al., 2007). However, LMTK3's biological characteristics, such as its subcellular localization and in vivo function, are unknown. In this study, we generated mouse mutants deficient for the Lmtk3 gene to dissect the molecular and physiological functions of LMTK3. We found that $L m t k 3^{-1-}$ mice exhibited prominent behavioral abnormalities, including locomotor hyperactivity, reduced anxiety, and decreased depression-like behavior, providing the first evidence for a physiological role of the LMTK kinase family in the CNS. Furthermore, we provided evidence that LMTK3, in neuronal endocytic vesicles, is implicated in endocytic trafficking of $N$-methyl-Daspartate receptor (NMDAR).

\section{Materials and Methods}

Reagents and antibodies

To generate a polyclonal antibody against LMTK3, a fragment of human LMTK3 (aa 784-850) was used as an immunogen. Antibodies were purified from sera of immunized rabbits by affinity chromatography. Rabbit polyclonal anti-GluN2B antibodies were described previously (Nakazawa et al., 2001). Commercially available antibodies used are as follows: mouse monoclonal anti- $\beta$-galactosidase (BML); mouse monoclonal anti-GM130, anti- 
EEA1, anti- $\alpha$-adaptin, and anti-Rab8 (BD Transduction Laboratories); mouse monoclonal anti-TfR (Zymed Laboratories); mouse monoclonal anti- $\alpha$-tubulin, anti-CYTH2 (5E11), and anti-synaptophysin (Sigma); rabbit polyclonal anti-GABA $\mathrm{A} \beta 2$, anti-GluN2A, and anti-GluA2, guinea pig polyclonal anti-VGLUT1, mouse monoclonal anti-GluN1, and anti-GluA1 (Millipore); mouse monoclonal anti-PSD-95 (Affinity Bioreagents); goat anti-rabbit-Alexa488, anti-mouse-Alexa488, anti-rabbit-Alexa555, antimouse-Alexa555, and anti-guinea pig-Alexa555 (Invitrogen); and anti-mouseCy5 (Jackson ImmunoResearch Laboratories). Alexa546-conjugated human transferrin was from Invitrogen.

\section{Generation of Lmtk3-knock-out (KO) mice}

A targeting vector for generation of Lmtk3-KO mice was constructed from a C57BL/6 BAC genomic clone (BACPAC Resources) and electroporated into TT2 ES cells (Yagi et al., 1993). Neomycin-resistant ES cell clones harboring the homologous recombination were screened by PCR and Southern blot analysis of genomic DNA with $5^{\prime}, 3^{\prime}$, and neo probes. Genotyping PCR was performed using Pr1 (5'-ctctcgtaccccaggagtttgagaacccgg- $\left.3^{\prime}\right), \operatorname{Pr} 2$ (5'-ctagagcggccgatttaaatacgtgctagc $\left.-3^{\prime}\right)$, and $\operatorname{Pr} 3\left(5^{\prime}\right.$-ggctcccaggttaagatctaggctgatggc $\left.-3^{\prime}\right)$ as the primers (Fig. 1 A,C). A total of three correctly targeted ES cell lines were injected into ICR 8-cell-stage embryos to generate chimeric mice. Germline-transmitted male chimeras were crossed with C57BL/6J female mice (Japan Clea) to obtain heterozygous F1 offspring (Accession no. CDB0764K, RIKEN). Experiments were performed with mice that had been backcrossed successively to C57BL/6J mice for at least seven generations. All animal experiments were performed following the guidelines for animal use issued by the Committee of Animal Experiments, University of Tokyo.

\section{$X$-Gal staining}

Brains were snap-frozen in Tissue-Tek OCT Compound (Sakura Finetek) and cryosectioned. Sections of $16 \mu \mathrm{m}$ in thickness were mounted on glass slides, fixed in $1 \% \mathrm{PFA}$, and stained overnight at $37^{\circ} \mathrm{C}$ in staining solution $(0.1 \% \mathrm{X}-\mathrm{Gal}, 2 \mathrm{~mm} \mathrm{MgCl}, 5 \mathrm{~mm}$ potassium ferricyanide, and $5 \mathrm{~mm}$ potassium ferrocyanide in PBS). Then, sections were dehydrated in ethanol and mounted. Images were acquired using a BZ9000 microscope (Keyence).

\section{Behavioral analysis}

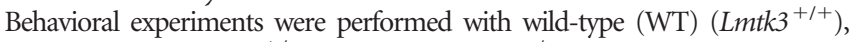
heterozygotes $\left(L m t k 3^{+/-}\right)$, and $\mathrm{KO}\left(L m t k 3^{-l-}\right)$ male littermates $(8-11$ weeks old), and all recordings were made blind with regard to genotype. Food consumption was measured by weighing the food daily for $7 \mathrm{~d}$. Behavioral tests were ranked from less stressful procedures to more aversive procedures, and tests were separated from one another by at least one day. Except for methylphenidate administration experiments (see below), the same cohort of mice was used for a battery of behavioral tests. The actual order of experiments was as follows: wire hang test, open-field test, elevated plus maze test, light/dark transition test, accelerating rotarod test, acoustic startle response and prepulse inhibition tests, tail flick test, contextual and auditory fear conditioning tests, tail suspension test, and forced swim test.

Wire hang test. Mice were placed on the wire mesh grid of a wire hang test apparatus (O'Hara \& Co.) and then inverted gently, so that they gripped the wire. Each mouse was tested twice, and the average latency to fall within $300 \mathrm{~s}$ was recorded manually.

Open-field test. The open-field test to measure spontaneous motor activity, exploratory behavior, and emotional responses in a novel environment was performed as described previously (Taniguchi et al., 2009). Briefly, each subject was placed in the center of an open-field apparatus $(50 \times 50 \times 33.3 \mathrm{~cm}$; width $\times$ depth $\times$ height $)$ illuminated at 150 lux and allowed to move freely for $15 \mathrm{~min}$. The total distance traveled in the arena, rearing activity, and the horizontal trajectory of mouse were recorded and analyzed using Image OFCR $1.00 \times$ and Image OF circle $1.01 \times$ (O'Hara \& Co.), modified software based on the public domain National Institutes of Health Image program. To analyze locomotor activity in a familiar environment, mice were first placed in the open-field apparatus for $60 \mathrm{~min}$ to become accustomed to the environment, returned to their home cages for $5 \mathrm{~min}$, and then placed in the open-field apparatus again, whereupon activity was measured for $15 \mathrm{~min}$. For investigation of the effects of methylphenidate, each mouse was placed in the open-field apparatus for $15 \mathrm{~min}$ before the injections (methylphenidate hydrochloride, Sigma; 0 [vehicle], 0.05, 0.3, 3, or $10 \mathrm{mg} / \mathrm{kg}$, i.p.). Horizontal and vertical activities were recorded automatically for $45 \mathrm{~min}$ after drug administration. Each mouse performed a single behavioral task in the drug administration experiment.

Elevated plus maze test. The elevated plus maze (EP-3002; O'Hara \& Co.) consisted of two open arms and two closed arms $(25 \times 5 \mathrm{~cm}$ each $)$ extending from a central area $(5 \times 5 \mathrm{~cm})$ and was elevated $50 \mathrm{~cm}$ from the ground. Mice were placed in the central square of the maze facing one of the open arms. Mouse behavior was recorded for $10 \mathrm{~min}$ under illumination of $\sim 300$ lux, using a Macintosh computer running Image EP $2.13 \times$ and Image EPC $2.03 \times$ (O'Hara \& Co.), modified software based on the public domain National Institutes of Health Image program. Total distance traveled in the maze, the number of entries into open or closed arms, and the time spent in open or closed arms were analyzed.

Light/dark transition test. The light-dark box consisted of two compartments: a transparent polyvinylchloride box (500 lux) and a black polyvinylchloride box (both $19 \times 19 \times 19 \mathrm{~cm}$ ). Two boxes were separated by a vertical sliding door that remained open $(5 \times 5 \mathrm{~cm})$. The amount of time spent in the transparent and black boxes and the transition number between two boxes were recorded for $15 \mathrm{~min}$.

Accelerating rotarod test. Mice were placed on a drum $(3 \mathrm{~cm}$ in diameter, O'Hara \& Co.) rotating at $4 \mathrm{rpm}$ at the beginning, and then the rotation of the rotarod was accelerated to $40 \mathrm{rpm}$ over a $300 \mathrm{~s}$ period at a constant rate. The latency to fall off the rotarod within the time period was measured. Mice were trained for two consecutive days, receiving four trials per day at intervals of $2 \mathrm{~h}$ between trials.

Acoustic startle response and prepulse inhibition tests. The startle reflex measurement system (SM-1001; Kinder Scientific) was used for assessing acoustic startle responses and prepulse inhibition. Mice were first placed in a Plexiglas chamber and were acclimated to the experimental condition for $2 \mathrm{~min}$. The startle response was recorded for $200 \mathrm{~ms}$ starting with the onset of the startle stimulus. The peak startle amplitude during the $200 \mathrm{~ms}$ sampling window was recorded as a measure of the startle response. A test session consisted of six trial types (i.e., five types for startle stimulus trials and one type for prepulse inhibition trial). The intensity of the startle stimulus was 70, 90,100,110, and $120 \mathrm{~dB}$ (each $40 \mathrm{~ms}$ ) with the background noise level at $70 \mathrm{~dB}$. The prepulse sound ( 75 or $80 \mathrm{~dB}$ ) was presented $100 \mathrm{~ms}$ before the startle stimulus $(120 \mathrm{~dB})$. Eight blocks of the six trial types were presented in pseudorandom order such that each trial type was presented once within a block with random intertrial intervals $(10-20 \mathrm{~s})$. The following formula was used to calculate percentage prepulse inhibition of the startle response: $100-[100 \times($ startle response on prepulse trials/startle response on $120 \mathrm{~dB}$ startle trials)].

Tail flick test. Animals were gently held by hand, and infrared light was applied to the tail $1.5 \mathrm{~cm}$ from its tip using a tail-flick unit (Model 7360; Ugo Basile). The latency time for removal of the tail from the stimulus was recorded in three consecutive trials at 10 s intervals. A cutoff time was set to $15 \mathrm{~s}$ to prevent thermal injury.

Contextual and auditory fear conditioning tests. Fear conditioning was conducted in a small conditioning chamber surrounded by a soundattenuating chest (CL-M3; O’Hara \& Co.). On day 1, mice were placed in the conditioning chamber for $170 \mathrm{~s}$ and then presented with a tone of 65 $\mathrm{dB} / 10 \mathrm{kHz}$ for $10 \mathrm{~s}$ followed by a foot shock $(2 \mathrm{~s} / 0.35 \mathrm{~mA})$. One minute after the foot shock, the mice were returned to their home cages. On day 2 , the mice were placed in the conditioning chamber for $6 \mathrm{~min}$. On day 3 , the mice were placed in a novel chamber with contexts different from those of the conditioning chamber for $180 \mathrm{~s}$ and then presented with the tone for $180 \mathrm{~s}$. Freezing responses were recorded during the tests and analyzed with Image FZC 2.22sr2 software (O'Hara \& Co.), modified software based on the public domain National Institutes of Health Image program.

Tail suspension test. Mice were suspended by the tail to a horizontal bar above the floor. Duration of immobility was recorded manually during a 6 min test session.

Forced swim test. Mice were placed in a cylinder filled with water at $23^{\circ} \mathrm{C}-25^{\circ} \mathrm{C}$. Duration of immobility (making only minimal movements to keep the head above the water or floating) was recorded manually 
during a 10 min test session. After testing, mice were removed and allowed to dry in a heated enclosure.

\section{Cell culture, transfection, and immunocytochemistry}

Cortical neurons were prepared from 16- to 17-day-old embryonic mice, cultured as described previously (Nakazawa et al., 2008), and transfected using Lipofectamine 2000 reagent (Invitrogen). Four hours after transfection, culture media were replaced with conditioned media, and cells were incubated for $48-72 \mathrm{~h}$. Cultured neurons grown on glass-bottomed dishes (MatTek) were fixed with 4\% PFA and 4\% sucrose in PBS and permeabilized with $0.2 \%$ Triton X-100 in PBS before immunolabeling. Images were acquired using a confocal laser-scanning microscope (FluoView FV1000, Olympus). Colocalization was evaluated quantitatively for Pearson's correlation coefficient $(r)$ from 10 to 20 cells using a FluoView FV1000 software.

\section{Biochemical fractionation}

Mouse brains were homogenized in ice-cold HEPES buffer using a Dounce homogenizer. After brain homogenate was centrifuged at $1000 \times g$, the supernatant was then recentrifuged at $12,500 \times g$ to obtain a crude synaptosomal fraction (P2) and a second supernatant (S2). The P2 fraction was lysed hypo-osmotically and centrifuged again to pellet a synaptosomal membrane fraction. The postsynaptic density fraction (PSD) was obtained by treating the synaptosomal membrane fraction with a HEPES-based buffer containing $1 \%$ Triton X-100. Preparation of the Golgi membrane fraction was performed using a discontinuous sucrose density gradient, as described previously (Sztul et al., 1991). Briefly, crude microsomal membranes from mouse brains were homogenized, adjusted to $1.25 \mathrm{~m}$ sucrose, and then layered onto a $1.84 \mathrm{M}$ sucrose cushion in an ultracentrifuge tube. The homogenate-sucrose layer was overlaid with $1.1 \mathrm{M}$ and $0.25 \mathrm{M}$ sucrose, and the sample was centrifuged at $120,000 \times g$ for $3 \mathrm{~h}$. Fractions were recovered from the $0.25 \mathrm{M} / 1.1 \mathrm{M}$ interface, the $1.1 \mathrm{M}$ region, and the $1.25 \mathrm{~m}$ region, and the protein concentration of each fraction was determined using a Bradford Protein assay (Bio-Rad).

\section{Surface biotinylation of cultured neurons}

Receptor biotinylation and endocytosis assays were performed using a cleavable biotin, as described previously (Roche et al., 2001). Surface proteins of primary cortical neuron cultures at DIV14 were biotinylated with $1 \mathrm{mg} / \mathrm{ml}$ sulfo-NHS-SS-biotin (Pierce) for $20 \mathrm{~min}$ at $4^{\circ} \mathrm{C}$. To collect surface proteins, cells were lysed with lysis buffer (20 mM HEPES, pH 7.5, $100 \mathrm{~mm} \mathrm{NaCl}, 1 \mathrm{~mm}$ EGTA, $1 \mathrm{~mm} \mathrm{Na} \mathrm{VO}_{4}, 1 \% \mathrm{NP}-40,1 \%$ sodium deoxycholate, $0.01 \%$ SDS, and protease inhibitor; Complete, Roche), and biotinylated proteins were precipitated with NeutrAvidin resins (Pierce). To collect endocytosed proteins, cells were incubated at $37^{\circ} \mathrm{C}$ for $30 \mathrm{~min}$ to allow for endocytosis. After cleavage of the remaining surface biotin with cleavage buffer ( $50 \mathrm{~mm}$ glutathione, $75 \mathrm{~mm} \mathrm{NaCl}, 10$ mM EDTA, $1 \%$ BSA, and $0.075 \mathrm{~N} \mathrm{NaOH}$ ), internalized biotinylated proteins were collected as above.

\section{Monoamine measurements by high-performance liquid chromatography with electrochemical detection}

Levels of monoamines and their metabolites were measured using highperformance liquid chromatography with electrochemical detection (HPLC-ECD). Male mice ( 8 weeks old) were killed by decapitation, and brain regions were rapidly dissected out and frozen at $-80^{\circ} \mathrm{C}$. Each sample was homogenized by ultrasonic irradiation in $0.2 \mathrm{M}$ perchloric acid containing isoproterenol as an internal standard. Homogenates were placed on ice for $30 \mathrm{~min}$ and centrifuged at $15,000 \times \mathrm{g}$ for $10 \mathrm{~min}$ at $4^{\circ} \mathrm{C}$. Supernatants were filtered through a syringe filter unit (DISMIC-3; Advantec). After the $\mathrm{pH}$ was adjusted to 3.0 by adding $1 \mathrm{~m}$ sodium acetate, supernatants were injected into an HPLC system equipped with an ODS column (Eicompak SC-5ODS, $3.0 \mathrm{~mm}$ id $\times 150 \mathrm{~mm}$; Eicom) and an electrochemical detector (EDC-100; Eicom) with the potential set at 750 $\mathrm{mV}$. Mobile phase consisted of $0.1 \mathrm{~m}$ citric acid and $0.1 \mathrm{~m}$ sodium acetate, $\mathrm{pH} 3.5$, containing sodium-1-octansulfonate (190 mg/L), EDTA-2Na (5 $\mathrm{mg} / \mathrm{L}$ ), and $13 \%$ methanol. The flow rate was set at $0.4 \mathrm{ml} / \mathrm{min}$. Protein content was assayed using the Lowry method after precipitates had been solubilized with $0.1 \mathrm{M} \mathrm{NaOH}$.

\section{Electrophysiology}

Standard procedures were used to prepare hippocampal slices $(400 \mu \mathrm{m}$ thick) from 7- to 10-week-old WT and littermate or age-matched $\mathrm{Lmtk}^{-1-}$ mice (Bongsebandhu-phubhakdi and Manabe, 2007). External solution contained the following (in $\mathrm{mm}$ ): $119 \mathrm{NaCl}, 2.5 \mathrm{KCl}, 1.3$ $\mathrm{MgSO}_{4}, 2.5 \mathrm{CaCl}_{2}, 1.0 \mathrm{NaH}_{2} \mathrm{PO}_{4}, 26.2 \mathrm{NaHCO}_{3}, 11$ glucose, and 0.1 picrotoxin (a $\gamma$-aminobutyric acid type A $\left[\mathrm{GABA}_{\mathrm{A}}\right]$-receptor antagonist). Synaptic responses were recorded from hippocampal slices at $25^{\circ} \mathrm{C}$ with whole-cell patch-clamp technique. A recording patch pipette (4-6 $\mathrm{M} \Omega$ ) filled with the internal solution containing the following (in $\mathrm{mm}$ ): 122.5 Cs gluconate, $17.5 \mathrm{CsCl}, 10 \mathrm{HEPES}, 0.2 \mathrm{EGTA}, 8 \mathrm{NaCl}, 2 \mathrm{Mg}$-ATP, and $0.3 \mathrm{Na}_{3}$-GTP, pH 7.2, 290-310 mOsm. To evoke synaptic responses, Schaffer collateral/commissural fibers were stimulated at $0.1 \mathrm{~Hz}$ with a bipolar tungsten electrode. The stimulus strength was adjusted to evoke AMPA EPSCs with a peak amplitude of 100-200 pA. AMPAR-mediated EPSCs were recorded at $-80 \mathrm{mV}$, and NMDAR-mediated EPSCs were recorded at $50 \mathrm{mV}$ with the same stimulus strength in the presence of 10 $\mu \mathrm{M}$ CNQX (a non-NMDAR antagonist). The series resistance was monitored throughout the experiment, and the data were discarded if it changed by $>20 \%$. An Axopatch-1D amplifier (Molecular Devices) was used to record synaptic responses. Data were digitized at $10 \mathrm{kHz}$ and analyzed on-line and off-line using pClamp software (Molecular Devices).

\section{Statistical analysis}

All data were expressed as mean \pm SEM. We used Student's $t$ test for biochemical analysis, one-way ANOVA for neurochemical analysis, physical and behavioral tests (open-field test, elevated plus maze test, light/dark transition test, wire hang test, and tail flick test), two-way ANOVA for acoustic startle response (ASR) and prepulse inhibition (PPI) test and open-field test of methylphenidate administration, and two-way repeated-measures ANOVA for open-field test, fear conditioning tests, tail suspension test, and forced swim test. Significant ANOVAs were followed up with Bonferroni's post hoc test. Values with $p<0.05$ were considered significant.

\section{Results}

\section{Generation of $L m t k 3^{-/-}$mice}

In mice, LMTK3 is predominantly expressed in the brain (Tomomura et al., 2007). To investigate the in vivo function of LMTK3 in the brain, we generated a null mutant mouse line by replacing a $3^{\prime}$ portion of exon 1 and the entire sequences of exons 2 and 3, which encode from the first methionine through part of the kinase domain, with a $L a c Z-n e o^{\mathrm{r}}$ cassette (Fig. 1A). Correct targeting of the cassette in ES cells was confirmed by Southern blot (Fig. 1B) and PCR analyses (Fig. 1C). Lmtk $3^{-1-}$ mutant mice were born at the Mendelian frequency expected from crossing Lmtk $3^{+/-}$heterozygotes. The absence of LMTK3 protein and expression of $\beta$-galactosidase in the mutant mice were confirmed by immunoblot analyses of brain lysates (Fig. $1 D$ ). We also verified that the expression of the Lmtk3-flanking gene, cytohesin 2 (CYTH2), was little affected by the insertion of the LacZ-neo ${ }^{\mathrm{r}}$ cassette into the Lmtk3 locus (Fig. 1D). To further analyze the expression pattern of $L m t k 3$ in brain, we performed X-gal staining of sagittal (Fig. 1E-G) and coronal (Fig. $1 H$ ) sections of the P1 Lmtk $3^{+-1-}$ brain and identified $\beta$-galactosidase-expressing cells. Expression of $\beta$-galactosidase was widely detected throughout the brain at low levels and was prominently observed in the hippocampus, cerebral cortex, and thalamus (Fig. $1 E, H$ ), largely consistent with its mRNA expression profile of our previous work (Kawa et al., 2004), and with immunohistochemical analysis by another group (Tomomura et al., 2007). In the hippocampus, $\mathrm{LaCZ}$ expression was clearly observed in the dentate gyrus and CA1, CA2, CA3 areas (Fig. $1 F$ ). In the cerebral motor cortex, expression was seen in layers II-VI, and more intense staining was observed in deeper layers (Fig. 1G). LacZ expression was almost undetectable in the striatum. 

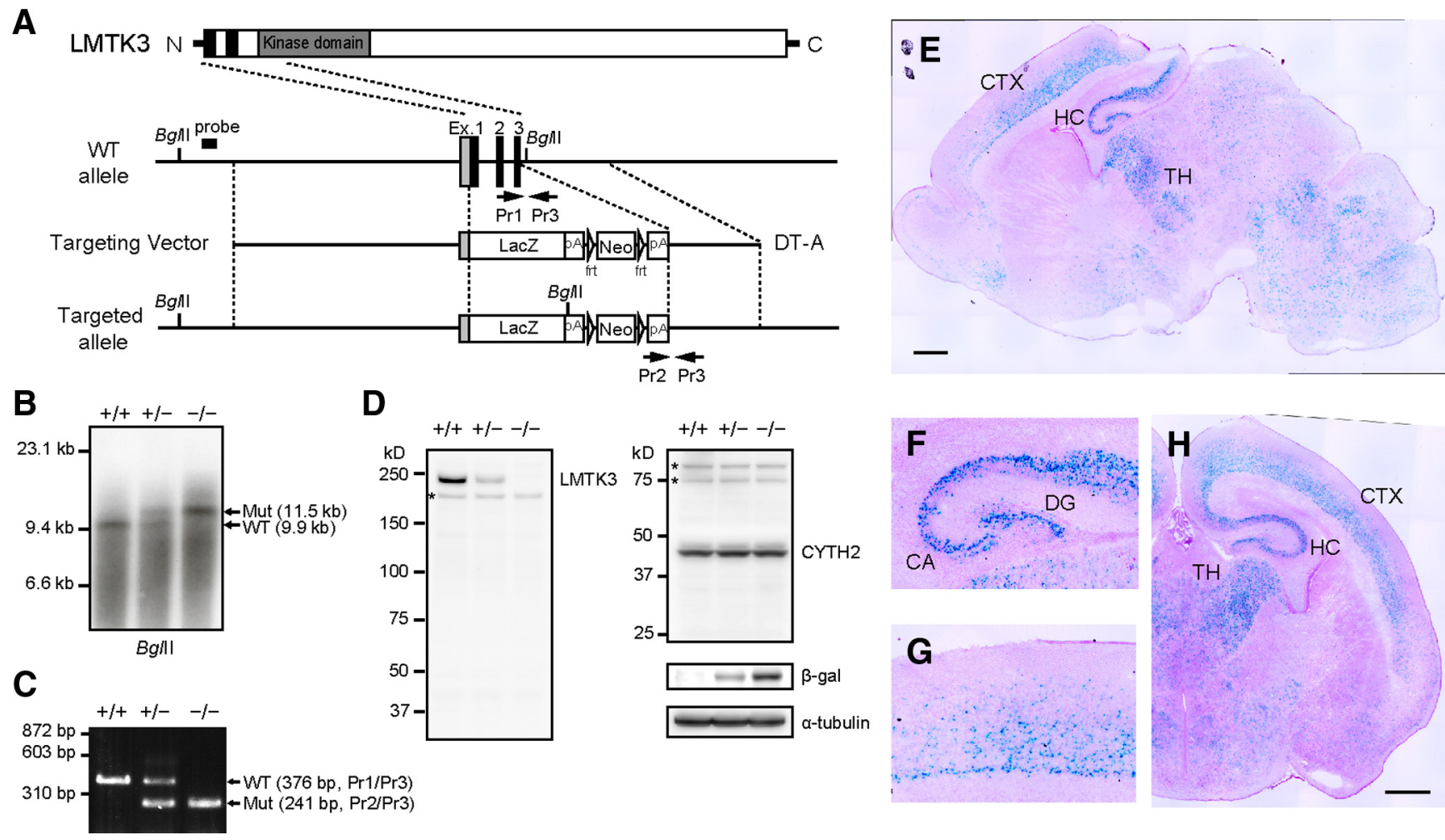

Figure 1. Expression profile of LMTK3 and generation of $L m t k 3^{-\prime-}$ mice. $A$, Schematic diagram of LMTK3, WT allele, a targeting vector, and a targeted allele after homologous recombination. Exons 1-3 encoding 1-120 aa of $L m t k 3$, which include N-terminal hydrophobic membrane targeting sequences (filled boxes) and a part of the Ser/Thr kinase domain (gray box) were replaced with lacZ and $\mathrm{NeO}^{\mathrm{r}}$. B. Tail genomic DNA [WT $(+/+)$, heterozygous mutant $(+/-)$, and homozygous mutant $(-/-)$ ] was digested with Bglll and hybridized with a 5 ' probe (indicated in $\left.\boldsymbol{A}\right)$ for Southern blot analysis. $C$, Genotyping PCR of tail genomic DNA [WT $(+/+)$, heterozygous mutant $(+/-)$, and homozygous mutant $(-/-)]$ using primers $\operatorname{Pr} 1, \operatorname{Pr} 2$, and $\operatorname{Pr} 3$ (indicated in $A)$. $\boldsymbol{D}$, Western blot analysis of WT $(+/+)$, heterozygous $(+/-)$, and homozygous $(-/-)$ mutant mouse brain. Newborn brain lysates were probed with anti-LMTK3, anti-CYTH2, anti- $\beta$-galactosidase, and anti- $\alpha$-tubulin antibodies. Asterisks indicate nonspecific signals. $\boldsymbol{E}-\boldsymbol{H}, \mathrm{X}$-Gal staining of sagittal $(\boldsymbol{E})$ and coronal $(\boldsymbol{H})$ sections of the P1 Lmtk $3^{+/-}$brain. $\boldsymbol{F}, \boldsymbol{G}$, High-magnification images of $\boldsymbol{E}$ to show strong expression in the cornu ammonis (CA) and dentate gyrus (DG) in the hippocampus (F) and prefrontal cortex (G). CTX, Cerebral cortex; HC, hippocampus; TH, thalamus. Scale bars: $\boldsymbol{E}, \boldsymbol{H}$, $0.5 \mathrm{~mm}$.

\section{Phenotypic characterization of $L m t k 3$-deficient mice}

Lmtk $3^{-1-}$ mice were viable and appeared to be grossly normal, suggesting that this protein is dispensable during embryonic and early postnatal development. Both male and female $L m t k 3^{-1-}$ mice appeared to be fertile, although female $L m t k 3^{-1-}$ mice rarely became pregnant after mating with $L m t k 3^{-1-}$ male mice. In contrast to Lmtk2 $2^{-1-}$ mice, which exhibited impaired spermatogenesis, no gross histological alterations were found in $L m t k 3^{-1-}$ mouse testes. Morphology and motility of caudal epididymal sperm were also normal in the Lmtk3 ${ }^{-1-}$ mouse. Considering the high expression levels of LMTK3 protein in the brain, we hypothesized that the marked reduction in fertility between $\mathrm{KO}$ male and female mice resulted from abnormalities in their social or sexual behavior.

Next, $L m t k 3^{-1-}$ mice and their WT littermates were subjected to a battery of physical and behavioral tests. We found that $L m t k 3^{-I-}$ mice weighed $\sim 10 \%$ less (WT, $25.03 \pm 0.55 \mathrm{~g}$; KO, $22.31 \pm 0.39 \mathrm{~g}, n=15$ for each genotype, $F_{(1,28)}=16.2, p<0.001$, one-way ANOVA) but consumed slightly more food than WT mice (average daily food intake per mouse over $7 \mathrm{~d}$ : WT, $3.14 \pm$ $0.14 \mathrm{~g} / \mathrm{d} ; \mathrm{KO}, 3.59 \pm 0.18 \mathrm{~g} / \mathrm{d}, n=8$ for each genotype, $F_{(1,14)}=$ $4.83, p=0.045$, one-way ANOVA). After adjusting for body weight, the observed difference in food intake was even more significant (WT, $0.114 \pm 0.005 \mathrm{~g} / \mathrm{BW} / \mathrm{d} ; \mathrm{KO}, 0.150 \pm 0.008$ $\mathrm{g} / \mathrm{BW} / \mathrm{d}, n=8$ for each genotype, $F_{(1,14)}=14.4, p=0.00198$, one-way ANOVA), indicating that mutant mice consumed more energy than WT controls, possibly because of their hyperactivity (see below). $L m t k 3^{-1-}$ mice showed no other abnormal physical characteristics or sensorimotor reflexes, including whisker touch, ear twitch, and eye blink. Intriguingly, however, $L m t k 3^{-/-}$mice showed a pronounced hyperactive phenotype in multiple tests. In the open-field test, overall locomotor activity in a novel environment was higher in KO mice than in their WT littermates, as evident from increased distance traveled (Fig. 2A,B), an increased number of vertical activities (Fig. 2C), and decreased immobility time (Fig. 2D) in $L m t k 3^{-/-}$, but not in $L m t k 3^{+/-}$ mice. $L m t k 3^{-1-}$ mice exhibited hyperactive horizontal, but not vertical, activity in the open-field apparatus, even after acclimation to the environment, indicating that $\mathrm{KO}$ mice are hyperactive not only in a novel, but also in a familiar, environment (Fig. $2 C-E)$. Lmtk $3^{-1-}$ mice also traveled longer distances in the elevated plus maze test (Fig. $2 F$ ). The total number of arm entries in the elevated plus maze test was also significantly greater in mutants (Fig. $2 G$ ). In the contextual and auditory fear conditioning tests, $L m t k 3^{-1-}$ mice showed reduced levels of freezing after shock and also during cued testing, which may be caused primarily by their hyperactive phenotype (Fig. $2 K-M$ ).

$L m t k 3^{-1-}$ mice also exhibited reduced anxiety behavior. The time spent in the open arms (Fig. $2 \mathrm{H}$ ) and the number of entries into the open arms (Fig. 2I) in the elevated plus maze test were increased. In the light/dark transition test, the number of transitions between light and dark was also significantly higher in mutant mice (Fig. $2 J$ ). Additionally, $\mathrm{KO}$ mice produced fewer fecal boli than WT mice during the open-field test (WT, $3.33 \pm 0.56$; 


\section{Open-field test}

A
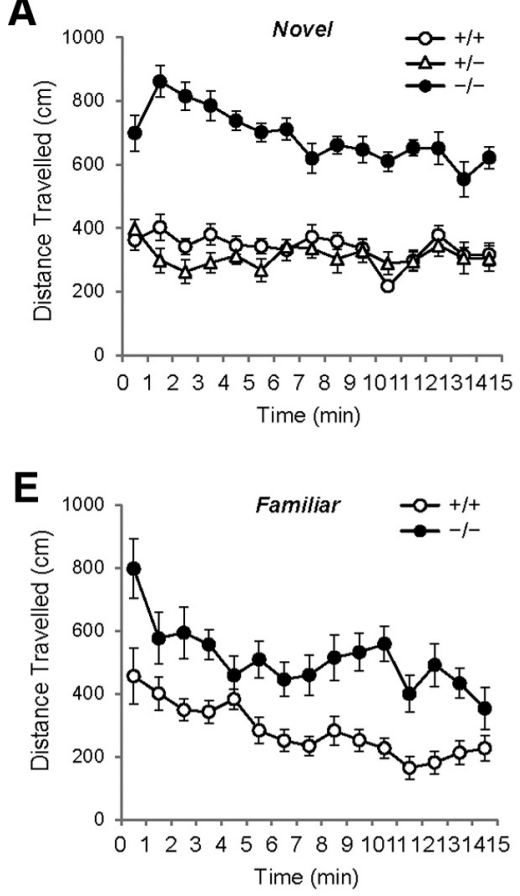

B

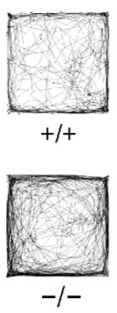

C

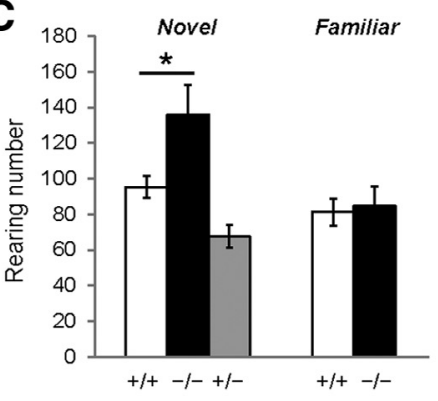

Elevated plus maze test

$\mathbf{F}$

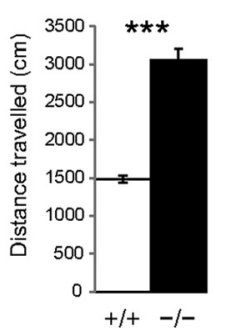

G

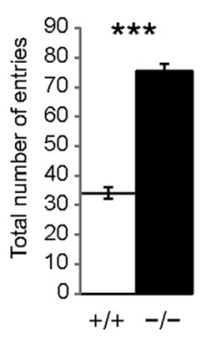

H

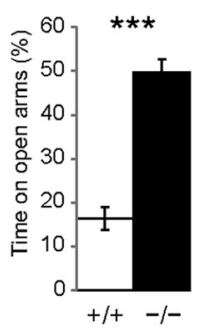

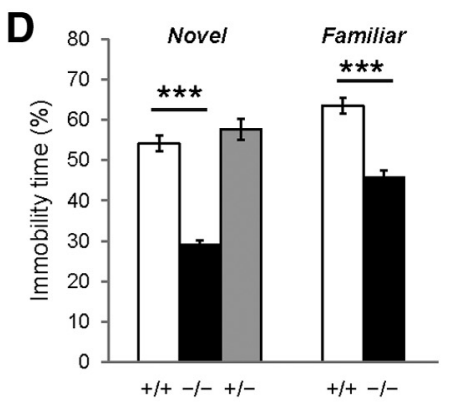

Contextual and auditory fear conditioning test
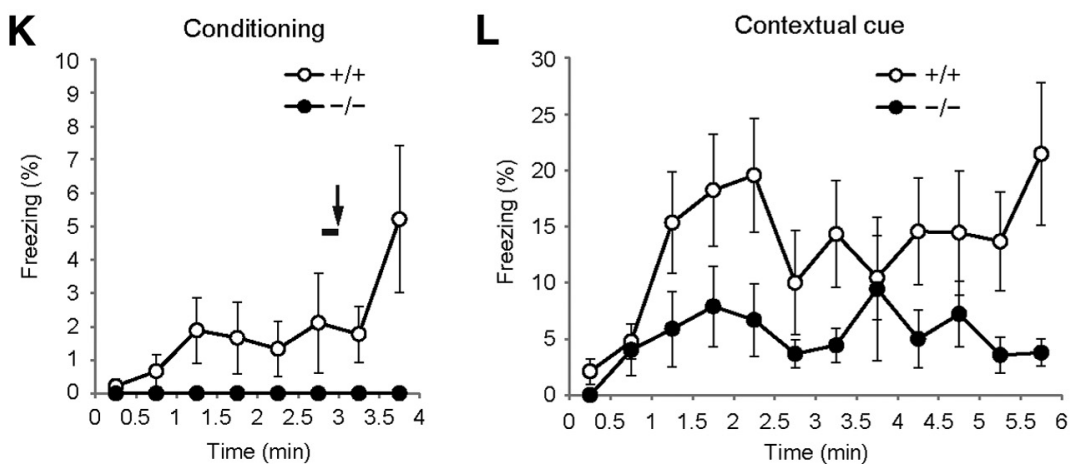

M

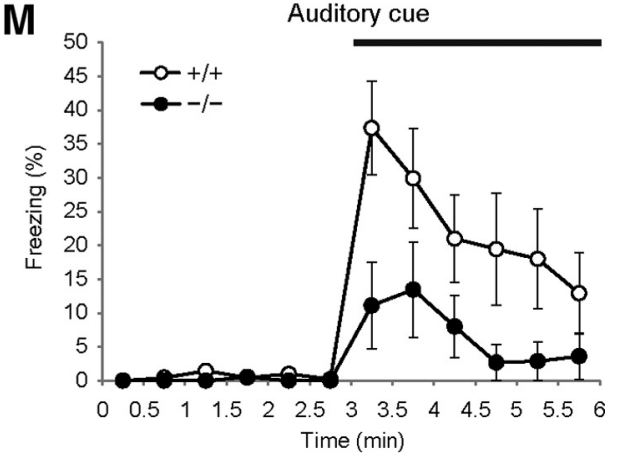

Figure 2. Hyperactive and reduced anxiety-like behaviors in $L m t k 3^{-1-}$ mice. $\boldsymbol{A}-\boldsymbol{E}$, The open-field test. $\boldsymbol{A}$, Increased horizontal activity of KO mice in a novel environment. WT, $n=10 ;$ Het, $n=$ $10 ; \mathrm{KO}, n=9 . F_{(2,26)}=97.61, p<0.0001$ for genotype, two-way repeated-measures ANOVA. WT versus K0: $p<0.0001$. B, Typical examples of locomotor patterns of WT (top) and KO (bottom) mice during 15 min recordings. $C$, Increased vertical activity in K0 mice in a novel environment. $n=7$ for each genotype. $F_{(1,12)}=5.34 .{ }^{*} p=0.0394$ for WT versus K0 in a novel environment, one-way ANOVA. $\boldsymbol{D}$, KO mice spent less time immobile in both novel and familiar environments. WT, $n=10 ; \mathrm{Het}, n=10 ; \mathrm{KO}, n=9 . F_{(1,17)}=119.59$. ${ }^{* * *} p<0.0001$ for WT versus K0 in a novel environment, $F_{(1,17)}=44.21 .{ }^{* * *} p<0.0001$ for WT versus $\mathrm{KO}$ in a familiar environment, one-way ANOVA. $\boldsymbol{E}$, Increased horizontal activity of KO mice in a familiar environment. WT, $n=10$; K0, $n=9 . F_{(1,17)}=29.72, p<0.0001$ for genotype, two-way repeated-measures ANOVA. $\boldsymbol{F}-\boldsymbol{I}$, The elevated plus maze test. $\boldsymbol{F}$, The increased total distance traveled by mutants. WT, $n=13 ; \mathrm{KO} 0, n=$ $11, F_{(1,22)}=117.8 .{ }^{* * *} p<0.0001$, one-way ANOVA. G, The increased total number of entries by mutants. WT, $n=13 ; \mathrm{KO}, n=11, F_{(1,22)}=170.1{ }^{* * *} p<0.0001$, one-way ANOVA. $\boldsymbol{H}$, Increased time spent in the open arms by the mutants. WT, $n=13 ; \mathrm{KO}, n=11, F_{(1,22)}=70.3$. ${ }^{* * *} p<0.0001$, one-way ANOVA.I, The increased number of entries into the open arms by mutants. WT, $n=$ $13 ; \mathrm{KO}, n=11, F_{(1,22)}=19.3$. ${ }^{* *} p<0.001$, one-way ANOVA.J, The increased number of transitions between the light and dark compartments by mutants during the light/dark transition test. $\mathrm{WT}, n=13 ; \mathrm{K} 0, n=11, F_{(1,22)}=36.8$. ${ }^{* *} p<0.0001$, one-way ANOVA. $\boldsymbol{K}-\boldsymbol{M}$, Contextual and auditory fear conditioning tests. $n=15$ for each genotype. $\boldsymbol{K}$, Freezing responses on the conditioning day. A tone was presented for $10 \mathrm{~s}$ (solid line), and mice were given a footshock for $2 \mathrm{~s}$ (arrow). $F_{(1,28)}=5.354, p=0.0282$ for genotype, two-way repeated-measures ANOVA. $L$, Freezing responses in the contextual fear conditioning test $24 \mathrm{~h}$ after conditioning. $F_{(1,28)}=4.896, p=0.0352$ for genotype, two-way repeated-measures ANOVA. $M$, Freezing responses in the auditory fear conditioning test $48 \mathrm{~h}$ after conditioning. Three minutes after putting mice into a test chamber with novel contexts, the same tone was presented for $3 \mathrm{~min}\left(\mathrm{solid}\right.$ line). $F_{(1,28)}=4.796, p=0.037$ for genotype, two-way repeated-measures ANOVA. Data are mean \pm SEM.

$\mathrm{KO}, 0.93 \pm 0.36, n=15$ for each genotype, $F_{(1,28)}=13.1, p=$ 0.00115 , one-way ANOVA), the elevated plus maze test (WT, $4.23 \pm 0.63, n=13$; KO, $0.27 \pm 0.19, n=11, F_{(1,22)}=30.9, p<$ 0.001 , one-way ANOVA), and the light/dark transition test (WT, $2.23 \pm 0.57, n=13 ; \mathrm{KO}, 0, n=11, F_{(1,22)}=12.97, p=0.0016$, one-way ANOVA), which also suggested decreased anxiety.

Furthermore, Lmtk3 ${ }^{-1-}$ mice showed decreased depressionlike behavior in the widely used tail suspension (Fig. $3 A, B$ ) and forced swim tests (Fig. 3C,D). In both tests, $L m t k 3^{-1-}$ mice were significantly less immobile than WT mice. Although all these $\mathrm{KO}$ mouse phenotypes could conceivably be explained simply as a function of their elevated motor activity, additional tests might further elucidate their antidepressant-like, anxiolytic-like, and attention-deficit/hyperactivity disorder (ADHD)-like behaviors.

We also performed the ASR and PPI tests to study the plasticity of sensorimotor information processing in mutant mice. 
Tail suspension test

A

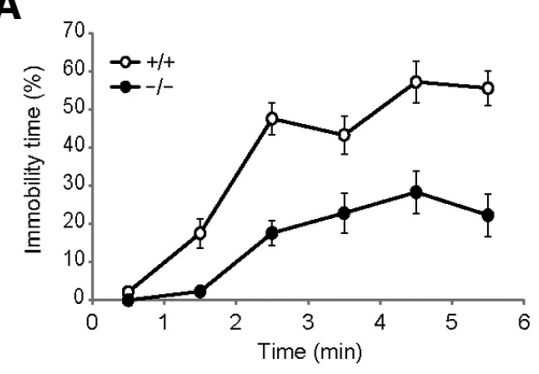

\section{Forced swim test}

C

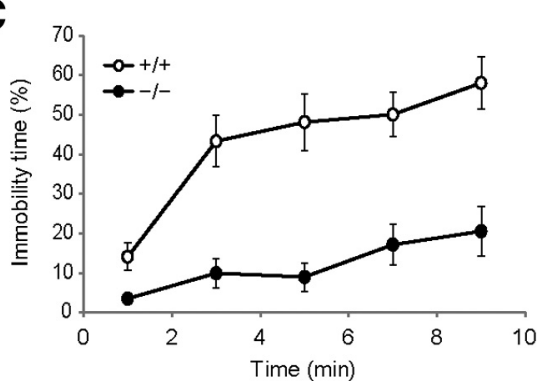

$\mathbf{D}$

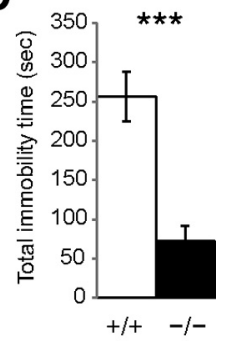

Figure 3. Antidepression-like behaviors in $L m t k 3^{-1-}$ mice. $\boldsymbol{A}, \boldsymbol{B}$, The tail suspension test. $\boldsymbol{A}$, The decreased percentage immobility time by mutants. WT, $n=12 ; \mathrm{K} 0, n=11, F_{(1,21)}=$ $30.81, p<0.0001$ for genotype, two-way repeated-measures ANOVA. $\boldsymbol{B}, A$ summary of the immobility time during the 6 min test. ${ }^{* * *} p<0.001$, one-way ANOVA. C, D, The forced swim test. $C$, The decreased percentage immobility time of mutants. WT, $n=13 ; \mathrm{K} 0, n=11, F_{(1,22)}$ $=22.33, p<0.0001$ for genotype, two-way repeated-measures ANOVA. D, A summary of the immobility time during the 10 min test. ${ }^{* * *} p<0.001$, one-way ANOVA. Data are mean \pm SEM.

\section{Acoustic startle response test}

\section{Prepulse inhibition}

A

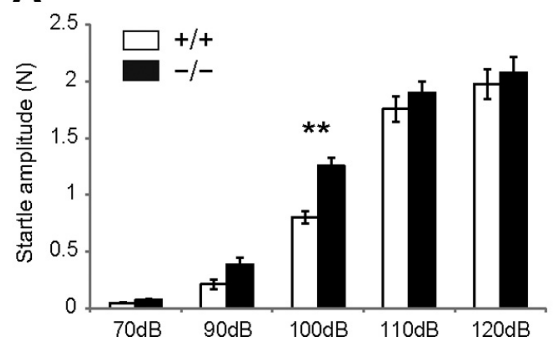

B

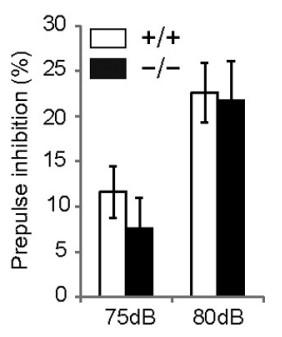

Figure 4. Behavioral analyses of $L m t k 3^{-I-}$ mice by acoustic startle response and prepulse inhibition tests. $A$, Mean amplitudes of startle responses to acoustic stimuli. WT, $n=13$; K0, $n=11$, two-way ANOVA. $F_{(4,110)}=1.853, p=0.1239$ for startle $\times$ genotype interaction; $F_{(1,110)}=11.23, p=0.0011$ for genotype, followed by Bonferroni's test. ${ }^{* *} p=0.0013$ for 100 dB. $\boldsymbol{B}$, Percentage prepulse inhibition. Prepulse sound at 75 or $80 \mathrm{~dB}$ was presented before the $120 \mathrm{~dB}$ startle stimuli. WT, $n=13 ; \mathrm{KO}, n=11$, two-way ANOVA. $F_{(1,44)}=0.5071, p=0.4801$ for genotype.

Whereas PPI was not significantly altered (Fig. 4B), a two-way ANOVA analysis of ASR revealed an overall significant difference between genotype (Fig. $4 A$ ), indicating that $L m t k 3^{-1-}$ mice displayed higher levels of ASR than $L m t k 3^{+/+}$mice, which may partly result from the elevated dopamine metabolism in the mutant mice (Table 1; see Discussion). Performance of KO and WT mice was not significantly different in the following tests: neuromuscular strength in the wire hang test (Fig. $5 A$ ), pain sensitivity in the tail flick test (Fig. $5 B$ ), and motor performance/coordination in the rotarod test (Fig. 5C).
Table 1. Monoamines and their metabolites in the striatum ${ }^{a}$

\begin{tabular}{|c|c|c|}
\hline Content or ratio & $\operatorname{Lmtk}^{+/+}$ & Lmtk3 $^{-I-}$ \\
\hline NE & $3.08 \pm 0.36$ & $4.01 \pm 1.08$ \\
\hline DA & $666.52 \pm 25.41$ & $667.30 \pm 21.30$ \\
\hline DOPAC & $38.40 \pm 1.03$ & $44.18 \pm 1.99^{*}$ \\
\hline HVA & $52.26 \pm 2.22$ & $59.24 \pm 2.48^{*}$ \\
\hline 3-MT & $27.86 \pm 0.85$ & $32.14 \pm 1.30^{*}$ \\
\hline$(\mathrm{DOPAC}+\mathrm{HVA}+3-\mathrm{MT}) / \mathrm{DA}$ & $0.179 \pm 0.005$ & $0.204 \pm 0.006^{* *}$ \\
\hline 5-HT & $22.99 \pm 1.21$ & $23.03 \pm 1.51$ \\
\hline 5-HIAA & $14.53 \pm 0.89$ & $15.12 \pm 0.94$ \\
\hline 5-HIAA/5-HT & $0.640 \pm 0.035$ & $0.669 \pm 0.035$ \\
\hline
\end{tabular}

${ }^{a}$ The values of neurochemical are shown as $\mathrm{pmol} / \mathrm{mg}$ of protein (mean $\pm \mathrm{SEM} ; n=14$ ). The turnovers of metabolites are shown as the ratio of the neurochemicals. NE, Norepinephrine; DA, dopamine.

${ }^{*} p<0.05$, compared with wild-type control.

${ }^{* *} p<0.01$, compared with wild-type control.
Wire hang test

A

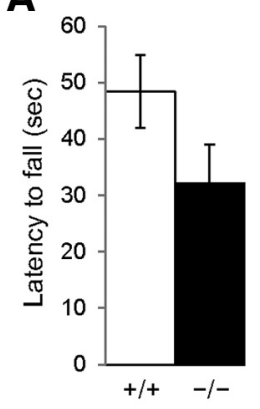

Tail flick test

B

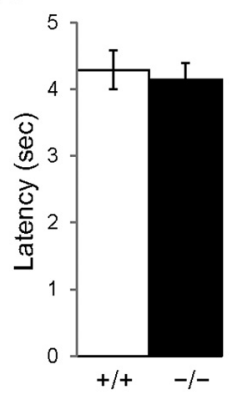

Accelerating rotarod test

c

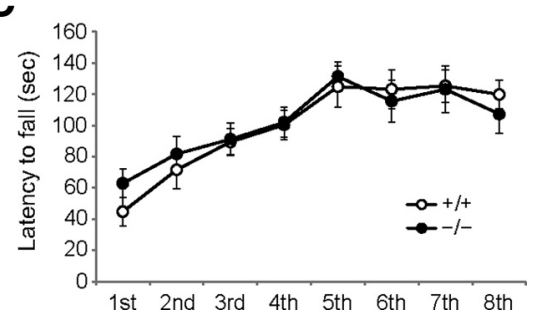

Figure 5. Behavioral analyses of $L m t k 3^{-1-}$ mice by wire hang, tail flick, and accelerating rotarod tests. $\boldsymbol{A}$, Wire hang test. Average latency to fall from the wire-mesh of two trials. $n=15$ for each genotype. $F_{(1,28)}=2.95, p=0.0967$, one-way ANOVA. $\boldsymbol{B}$, Tail flick test. Average tail flick latency in response to heat stimulus over three trials. WT, $n=13 ; \mathrm{KO}, n=12, F_{(1,23)}=$ $0.137, p=0.704$, one-way ANOVA. C, Accelerating rotarod test. Mice were trained for eight trials, four trials per day for two consecutive days. $n=15$ for each genotype. $F_{(1,28)}=0.130$, $p=0.718$, two-way repeated-measures ANOVA.

Elevated striatal dopamine turnover rate in $\mathbf{L m t k} 3^{-/-}$mice Because locomotor hyperactivity in mice is often associated with increased levels of dopamine and other monoamines, we next examined the possibility of a neurochemical imbalance in Lmtk $3^{-1-}$ mice by measuring monoamines and their metabolite levels in the prefrontal cortex, hippocampus, and striatum. HPLC analysis revealed that the dopamine turnover ratio ([3,4dihydroxyphenylacetic acid (DOPAC) + homovanillic acid (HVA) + 3-methoxytyramine (3-MT)]/dopamine) was significantly increased in the striata of $\mathrm{KO}$ mice $\left(n=14, F_{(1,26)}=10.15\right.$, $p=0.0037$, one-way ANOVA) (Table 1 ). Levels of DOPAC, HVA, and 3-MT were elevated in $L m t k 3^{-1-}$ mice compared with WT mice $\left(n=14, F_{(1,26)}=6.67, p=0.0158\right.$ for DOPAC; $F_{(1,26)}=$ $4.41, p=0.0457$ for HVA; $F_{(1,26)}=7.62, p=0.0104$ for $3-\mathrm{MT}$, one-way ANOVA), whereas dopamine levels were unchanged $\left(n=14, F_{(1,26)}=0.0005, p=0.982\right.$, one-way ANOVA). Levels of 


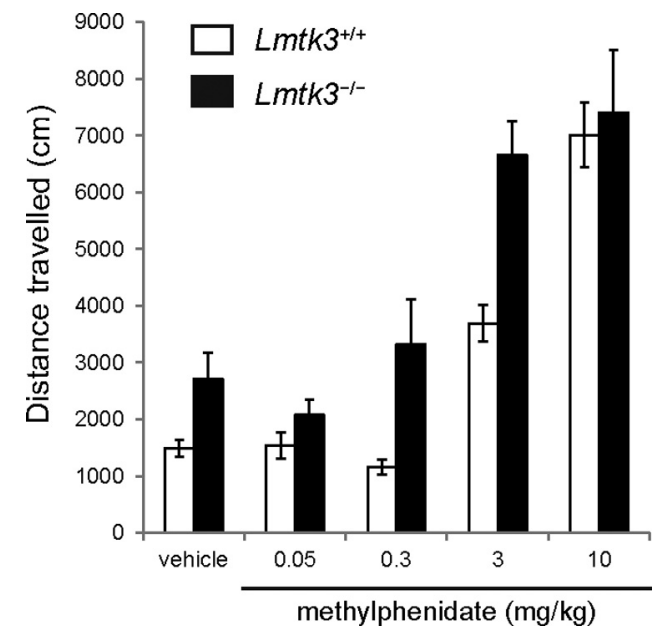

Figure 6. Effects of methylphenidate on locomotor activity. Horizontal activity was measured in the open-field test for $45 \mathrm{~min}$ after the injection of methylphenidate at the doses indicated ( $n=12$ [WT], $n=8$ [KO] for vehicle (saline); $n=4$ [WT], $n=10$ [K0] for 0.05 $\mathrm{mg} / \mathrm{kg} ; n=5$ [WT], $n=4$ [K0] for $0.3 \mathrm{mg} / \mathrm{kg} ; n=10$ [WT], $n=6[\mathrm{KO}]$ for $3 \mathrm{mg} / \mathrm{kg} ; n=11$ [WT], $n=8[\mathrm{KO}]$ for $10 \mathrm{mg} / \mathrm{kg}) . F_{(4,68)}=1.895, p=0.1214$ for dose $\times$ genotype interaction; $F_{(1,68)}=15.34, p=0.0002$ for genotype, two-way repeated-measures ANOVA, followed by Bonferroni's test. Data are mean \pm SEM.

norepinephrine $\left(n=14, F_{(1,26)}=0.666, p=0.422\right.$, one-way ANOVA), 5-hydroxytryptamine (5-HT) $\left(n=14, F_{(1,26)}=\right.$ $0.0004, p=0.985$, one-way ANOVA), and 5-hydroxyindoleacetic acid (5-HIAA) $\left(n=14, F_{(1,26)}=0.212, p=0.649\right.$, one-way ANOVA) and the serotonin turnover ratio (5-HIAA/5-HT, $n=$ $14, F_{(1,26)}=0.330, p=0.571$, one-way ANOVA) were similar between $L m t k 3^{-1-}$ and WT mice. These observations suggest that $L m t k 3^{-1-}$ mice have an elevated rate of dopamine metabolism, which may at least partly explain their hyperactive phenotype. No significant alterations in the levels of norepinephrine, dopamine, DOPAC, HVA, 5-HT, or 5-HIAA were detected in the prefrontal cortex or hippocampus between mutant and WT mice (data not shown). As LMTK3 expression is lower in basal ganglia than in the prefrontal cortex and hippocampus (Fig. 1E), the observed effect of LMTK3 on dopamine turnover may be minor or indirect.

\section{Effect of methylphenidate on the locomotor activity of} Lmtk $3^{-1-}$ mice

Lmtk3 ${ }^{-1-}$ mice were challenged with varying concentrations of methylphenidate, a psycho-stimulant most commonly used for the treatment of ADHD, and behavioral responses were evaluated by horizontal and vertical locomotor activities in the openfield test (Fig. 6). Because high doses of methylphenidate (30 $\mathrm{mg} / \mathrm{kg}$ ) induces persistent stereotypic behaviors, which were manifested in terms of decreased horizontal activity, we present the pharmacological effects of the drug only in the $0.05-10 \mathrm{mg} / \mathrm{kg}$ range. $L m t k 3^{-1-}$ mice differed from littermate controls in their response to the drug. Although $L m t k 3^{-1-}$ mice tended to manifest horizontal activity comparable with the levels of WT mice at the lowest dose $(0.05 \mathrm{mg} / \mathrm{kg}$, i.p.), overall locomotor activity was still significantly higher in $\mathrm{KO}$ mice after administration of the drug at higher doses. Furthermore, the maximum level of horizontal activity was achieved at $3 \mathrm{mg} / \mathrm{kg}$ in mutant mice, whereas a $10 \mathrm{mg} / \mathrm{kg}$ dose was required for WT mice, indicating a difference in sensitivity to methylphenidate between the two genotypes.

\section{Intracellular distribution of LMTK3}

To help dissect the molecular basis of the abnormal phenotypes (hyperlocomotion, reduced anxiety, and/or decreased depression) of $L m t k 3^{-1-}$ mice, we analyzed the subcellular localization of endogenous LMTK3 protein in cultured primary neurons. Cultured cortical neurons prepared from WT and $L m t k 3^{-1-}$ mouse embryos were immunostained with anti-LMTK3 antibody. LMTK3 was enriched at a perinuclear structure around the GM130-positive Golgi membranes $(r=0.21 \pm 0.038)$ and present as a dotted pattern throughout the neurites (Fig. 7A). When neurons were serum-starved for $1 \mathrm{~h}$ and incubated with Alexa546-conjugated transferrin (Tf) for $30 \mathrm{~min}$ to label endosomal vesicles, LMTK3 clearly colocalized with internalized Tfpositive vesicles $(r=0.61 \pm 0.033)$ (Fig. $7 B)$. We also found that a fraction $(22.7 \pm 1.37 \%)$ of LMTK3-positive dotted structures in the neurites were present in the close vicinity of PSD-95/ VGLUT1-positive excitatory synapses (Fig. 7C). Morphological properties of neurons, such as neurite length or the shape and number of spines, did not markedly differ between the $L m t k 3^{+/+}$ and $L m t k 3^{-1-}$ neurons (Fig. 7D).

Next, we analyzed the distribution of LMTK3 biochemically using fractionated brain lysates. Mouse brain homogenate was separated into several fractions by differential centrifugation. LMTK3 was found in the synaptosomal membrane fraction and was heavily enriched in Triton-X-insoluble postsynaptic fractions, together with PSD-95 (Fig. 7E). When homogenate was applied to a discontinuous sucrose density gradient (Fig. $7 F$ ), the Golgi membrane-enriched fraction appeared at the $0.25 \mathrm{M} / 1.1 \mathrm{M}$ sucrose interface, as was evident from enrichment of GM130 and Rab8, a GTPase that localizes to the trans-Golgi network. Early endosomal protein, EEA1, was not detected in this fraction. LMTK3 was most abundant in the Golgi membrane-enriched fraction, which was consistent with the immunocytochemical localization of LMTK3 near the Golgi complex. EEA1 was present in the $1.25 \mathrm{M}$ sucrose fraction where LMTK3, but not Golgi protein, was present. Notably, we also found that LMTK3 forms a complex with the AP-2 clathrin adaptor through a coimmunoprecipitation experiment (Fig. $7 G$ ). These properties of LMTK3, together with the immunocytochemical identification of LMTK3 in endosomal structures in cultured cells, suggest that LMTK3 plays a role in endosomal vesicle trafficking at neuronal synapses.

\section{Impaired NMDA receptor trafficking in LMTK3-deficient cultured neurons}

To test whether LMTK3 functions in membrane protein trafficking in neurons, we examined basal levels of receptor internalization in cultured cortical neurons from $L m t k 3^{+/+}$and $L m t k 3^{-1-}$ mice by cell surface biotinylation (Fig. $8 A, B$ ). Neither total protein nor surface levels of any membrane proteins examined were significantly different between $L m t k 3^{+/+}$and $L m t k 3^{-1-}$ neurons. Interestingly, however, LMTK3 deficiency caused a significant increase in the intracellular levels of the GluN1 and GluN2B subunits of the NMDA receptor due most likely to increased internalization and/or decreased export of intracellular receptors to the cell surface. The intracellular level of the GluN2A subunit was also slightly higher in $L m t k 3^{-1-}$ neuron, but the difference was not significant $(p=0.17)$. In contrast, intracellular GluA1 and GluA2 subunits of $\alpha$-amino-3-hydroxy-5-methylisoxazole-4-propionic-acid (AMPA) receptor, transferrin receptor, and the $\beta 2$ subunit of $\mathrm{GABA}_{\mathrm{A}}$ receptor appeared to be at comparable levels in $L m t k 3^{+/+}$and $L m t k 3^{-1-}$ neurons. An immunocytochemical analysis of LMTK3 and the GluN1 NMDAR subunit in cultured cortical neurons revealed that a fraction of the 
A
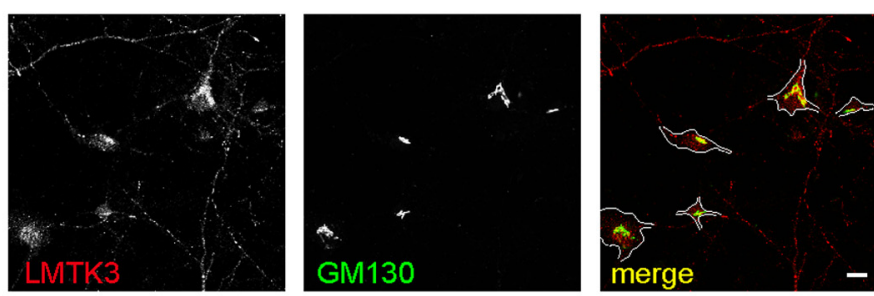

B

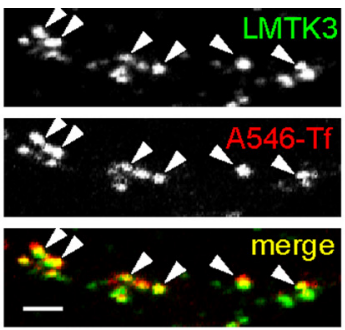

C

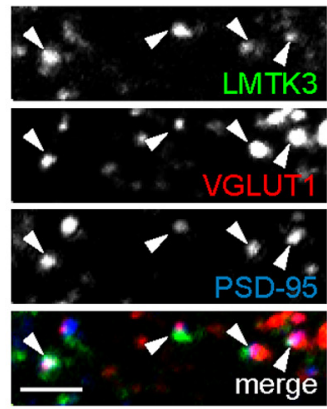

E

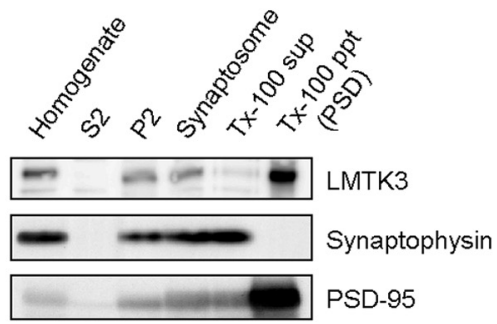

D

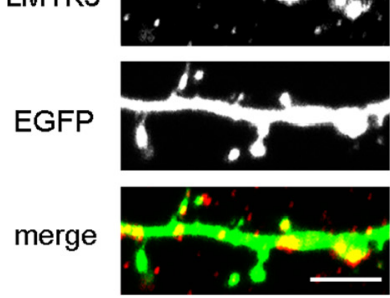

F

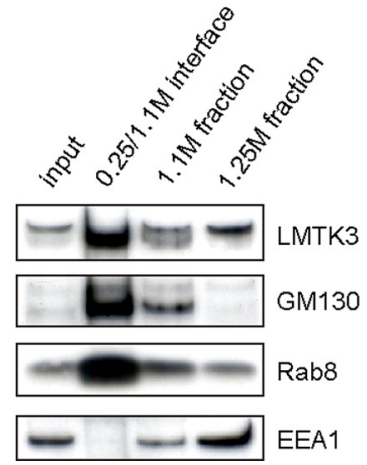

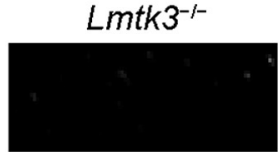
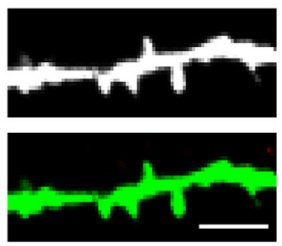

G
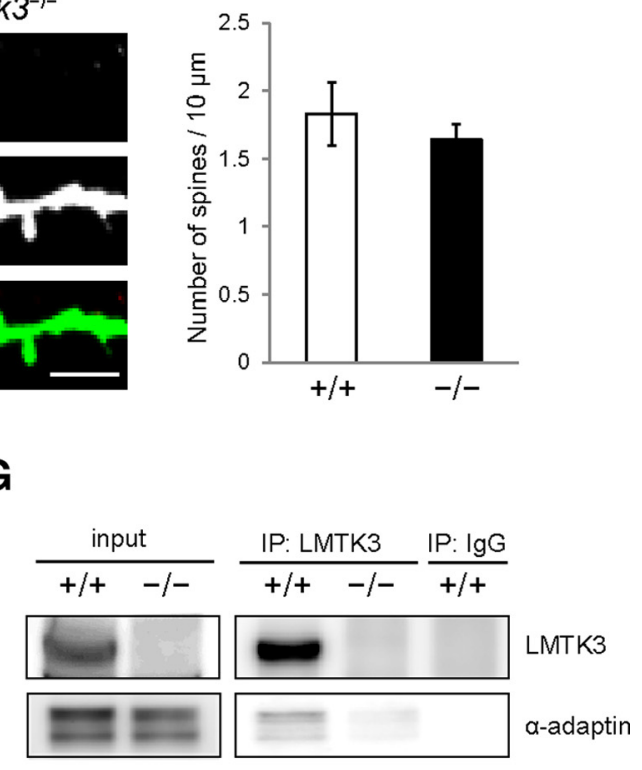

Figure 7. Subcellular distribution of LMTK3. A, Cultured cortical neurons (DIV7) were immunostained with anti-LMTK3 (red) and anti-GM130 (green) antibodies. Neuronal somas were outlined in the merged image for clarification of the cell shape. Scale bar, $10 \mu \mathrm{m}$. B, Cultured cortical neurons (DIV14) were labeled with Alexa546-Tf (red) and immunostained with anti-LMTK3 antibody (green). Arrowheads indicate the colocalization of LMTK3 with Tf-positive endosomal vesicles in the neurites. Scale bar, $2 \mu \mathrm{m}$. C, Cultured cortical neurons (DIV14) were immunostained with anti-LMTK3 (green), anti-VGLUT1 (red), and anti-PSD-95 (blue) antibodies. Arrowheads indicate the presence of LMTK3 in the close vicinity of VGLUT1/PSD-95-positive excitatory synapses. Scale bar, $2 \mu \mathrm{m}$. D. Cultured cortical neurons (DIV14) from $L m t k 3^{+/+}$(left) and $L m t k 3^{-1-}$ (right) embryos were transfected with EGFP expression plasmid. Two days after transfection, neurons were immunostained with anti-LMTK3 (red) and anti-GFP (green) antibodies. LMTK3 immunofluorescence was confirmed to be rarely detectable in $L m t k 3^{-1-}$ neurons. Neuronal morphology was assessed by GFP immunofluorescence. Spine densities were also quantified ( $n>50$ neurites in EGFP-expressing neurons of each genotype; $p=0.56$ ). Scale bar, $10 \mu \mathrm{m}$. $E$, Biochemical fractionation of mouse brain lysate. An equal amount of protein from each fraction was probed with anti-LMTK3, anti-synaptophysin, and anti-PSD-95 antibodies. $\boldsymbol{F}$, Biochemical preparation of the Golgi membrane fraction from mouse brain lysate by discontinuous sucrose density gradient. Equal amount proteins of each fraction were probed with anti-LMTK3, anti-GM130, anti-Rab8, and anti-EEA1 antibodies. G, Lysates from $L m t k 3^{+/+}$or $L m t k 3^{-/-}$mouse brains were immunoprecipitated with an anti-LMTK3 antibody or a control rabbit lg G and analyzed using anti- $\alpha$-adaptin antibody. Data are mean \pm SEM; Student's $t$ test.

LMTK3 protein was targeted to NMDAR-positive vesicles (Fig. $8 C$ ). These results strongly suggest the involvement of LMTK3 in the endocytic trafficking of NMDA receptor, preferentially containing GluN1 and GluN2B subunits, in neurons.

\section{Basic properties of synaptic transmission in}

\section{LMTK3-deficient mice}

To examine whether the basic properties of synaptic transmission were altered in $L m t k 3^{-1-}$ mice, we performed electrophysiological experiments using hippocampal slices where LMTK3 is most prominently expressed in the brain (Fig. 1E,F) (Kawa et al., 2004; Tomomura et al., 2007). The ratio of NMDAR-mediated EPSC amplitudes to AMPAR-mediated EPSC amplitudes did not differ significantly between WT and KO mice (WT: $0.63 \pm 0.06, n=10$; KO: $0.75 \pm 0.06, n=11, p=0.204)$. AMPAR-mediated synaptic responses seemed to be unaltered, as judged by the similar surface expression level of AMPAR in WT and KO neurons (Fig. 8A,B), and the comparable stimulus strength required for evoking sim- ilar amplitudes of AMPA EPSCs (100-200 pA) between two genotypes (WT: $1.33 \pm 0.05 \mathrm{~V}, n=11 ; \mathrm{KO}: 1.48 \pm 0.07 \mathrm{~V} ; n=12$, $p=0.120)$. NMDA current kinetics was not significantly changed in $\mathrm{KO}$ mice (rise time, WT: $7.08 \pm 0.18 \mathrm{~ms}, n=10$; KO: $6.68 \pm$ $0.11 \mathrm{~ms}, n=11 ; p=0.083$; decay time constant, WT: $62.01 \pm$ $2.88 \mathrm{~ms}, n=10$; KO: $66.97 \pm 2.17 \mathrm{~ms}, n=11 ; p=0.209$ ), suggesting that the subunit composition of the synaptic NMDAR is not affected. These results suggested that the basal synaptic efficacy was normal in $\mathrm{KO}$ mice. We consider that this result is consistent with our biochemical data in which the steady-state surface expression levels of NMDARs were not significantly different between WT and $\mathrm{KO}$ neurons (Fig. $8 A, B$ ).

\section{Discussion}

Despite the high expression levels of LMTK family kinases in the CNS, their neuronal functions in vivo have not yet been characterized. In this study, we performed a comprehensive behavioral analysis of $L m t k 3-\mathrm{KO}$ mice, and the results implicated LMTK3 in 
A

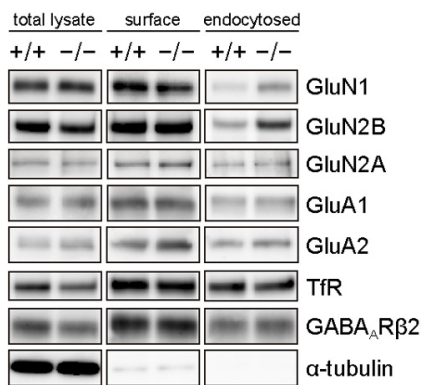

C

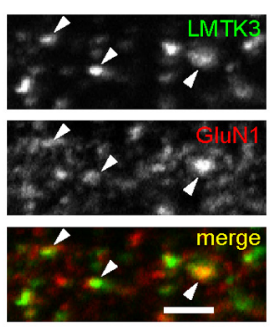

B

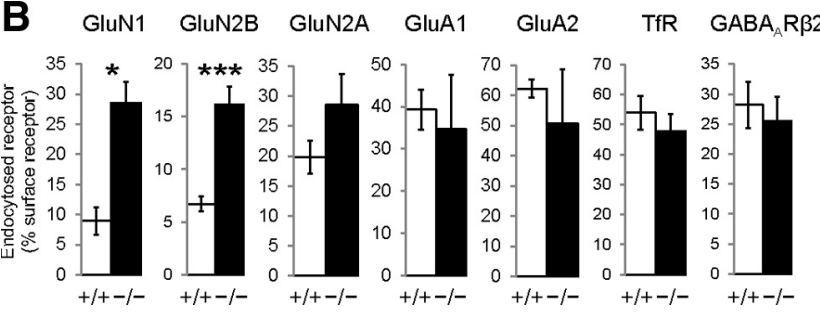

Figure 8. Impaired NMDA receptor trafficking in $L m t k 3^{-1-}$ neurons. A, Biotinylation of surface proteins and endocytosis were performed as described in Materials and Methods. Total lysates, surface proteins, and endocytosed proteins of WT and KO neurons (DIV14) were analyzed by immunoblotting for GluN1, GluN2B, GluN2A, GluA1, TfR, GABA ${ }_{A} R \beta 2$, and $\alpha$-tubulin. Negligible $\alpha$-tubulin immunoreactivity in "surface" and "endocytosed" lanes indicates successful biotin labeling and quenching of the surface proteins. $B$, Quantification of the immunoblot of A. $n=5$ for GluN2B, GluN2A, and TfR; $n=3$ for GluN1, GluA1, GluA2, and GABA $A_{A} R \beta 2$. Data are mean \pm SEM. ${ }^{*} p<0.05$, Student's $t$ test. ${ }^{* * *} p<0.001$, Student's $t$ test. $C$, Cultured cortical neurons (DIV14) were immunostained with anti-LMTK3 (green) and anti-GluN1 (red) antibodies. Arrowheads indicate partial colocalization of LMTK3 with the NMDA receptors. Scale bar, 2 $\mu \mathrm{m}$.

the regulation of locomotor behaviors. Namely, disruption of the Lmtk3 gene in mice leads to a profound increase in locomotor activity not only in a novel, but also in a familiar environment. Lmtk $3^{-1-}$ mice also show reduced anxiety-like behavior and decreased depression-like behavior, which might be linked to the increased locomotor activity.

As dopamine is involved in regulation of movement, emotion, motivation, cognition, learning, and reward-seeking behavior (Yao et al., 2008), dysregulation of the dopaminergic system is correlated with pathological states, such as schizophrenia, Parkinson's disease, and ADHD (Arias-Carrion and Poppel, 2007). Therefore, the observed increase in the striatal dopamine turnover rate might explain, at least partially, the hyperactive state of Lmtk $3^{-1-}$ mice, although more detailed analysis concerning the extracellular monoamine levels needs to be performed. Because dopamine has also been implicated in anxiety, as exemplified by the anxiety-related phenotypes of $\mathrm{D}_{3}$ dopamine receptor- and dopamine transporter (DAT)-deficient mice (Steiner et al., 1997) (Pogorelov et al., 2005), alterations in the dopamine system may explain the less anxious phenotype of $L m t k 3^{-1-}$ mice. In addition, $L m t k 3^{-1-}$ mice showed a significant increase in the ASR (Fig. 4A). It is currently unknown whether the increase in ASR amplitudes in mutant mice is the result of an increase in auditory processing or changes in control of modulatory neural circuits of the startle pathway (Koch, 1999). Notably, dopamine neurotransmission is involved in the ASR and in PPI (Zhang et al., 2000), and an increase in the ASR is also observed in DATknockdown mice (Ralph-Williams et al., 2003). It is also noteworthy that mutant mice lacking the GluN2B gene heterogeneously exhibited enhanced ASR (Takeuchi et al., 2001). Thus, dopamine- and/or glutamine-induced changes in sen- sory information processing in LMTK3 mutant mice may at least in part account for the enhancement of the ASR.

Locomotor hyperactivity is a key clinical symptom of ADHD. $\mathrm{ADHD}$ is a heterogeneous disorder, and a number of animal models with different defects induced by genetic or pharmacological alterations have been proposed (Russell et al., 2005; Russell, 2011). Lmtk3 ${ }^{-1-}$ mice displayed pronounced hyperactivity in all the behavioral studies in which locomotor activity was measured, suggesting that mutant mice may serve as an additional model for ADHD. This issue was addressed by assessing the pharmacological effects of methylphenidate on locomotor hyperactivity in LMTK3 mutant mice. In contrast to the widely investigated ADHD models, such as spontaneously hypertensive rats (SHR) or DAT-KO mice (Wultz et al., 1990; Gainetdinov et al., 1999), Lmtk3 ${ }^{-1-}$ exhibited a still higher locomotor activity by the administration of the drug. Therefore, the issue of whether or not $L m t k 3^{-1-}$ mice serve as an ADHD model needs further careful validation.

The NMDA receptor is critical for development, synaptic plasticity, and neuronal excitotoxicity. Treatment with NMDAR antagonists produces antidepressant effects in behavioral tasks. Involvement of the glutamatergic pathway in emotional regulation is evident in mice with genetically engineered NMDA receptor genes (Nakazawa et al., 2006; Taniguchi et al., 2009). Such mice show alteration in depression- and/or anxiety-related behaviors. The increased intracellular level of NMDA receptors in the LMTK3-deficient, compared with the WT, primary neurons may cause the observed unusual phenotypes, such as anxiolytic and antidepressant behaviors. As the NMDA receptor is widely expressed in brain, including the cortex, hippocampus, striatum, amygdala, etc., imbalance in endocytic trafficking of NMDA receptors could impact synaptic transmission, which could, in turn cause abnormal phenotypes in various brain regions, such as the elevated dopamine turnover in the striatum. In hippocampus and cortex, NMDA receptors consist of GluN1/ GluN2A, GluN1/GluN2B heterodimers and less abundant GluN1/GluN2A/GluN2B heterotrimer (Sheng et al., 1994; Sans et al., 2000). The GluN2 subunits contain distinct intracellular trafficking motifs that regulate the postendocytic itineraries of the NMDAR; GluN2A-containing receptors predominantly undergo lysosomal sorting for degradation, whereas GluN2Bcontaining receptors preferentially traffic through the recycling pathway (Lavezzari et al., 2004; Tang et al., 2010). Our biochemical analysis suggests that LMTK3 may have a specific role in the regulation of the GluN2B-containing NMDAR through recycling pathway, such as LMTK1 and LMTK2, both of which have been implicated in the recycling endosomal trafficking (Chibalina et al., 2007; Inoue et al., 2008; Takano et al., 2010). Although the intracellular level of NMDA receptors was increased in LMTK3deficient cultured primary neurons, total or surface levels of NMDA receptors appeared little affected by the absence of LMTK3. One possible explanation is that there may be homeostatic mechanisms that sense the altered receptor expression level on the cell surface and keep the receptor number constant. Similar regulation has also been observed for AMPA receptors (Man et al., 2000) and NMDA receptors (Nakazawa et al., 2006), where impaired receptor internalization did not alter the surface receptor number. More precise measurements of surface levels of NMDA receptors with not only cultured cells, but also various brain tissues of $L m t k 3^{-1-}$ mice need to be performed.

The molecular mechanism by which LMTK3 contributes to dopamine systems and to NMDAR trafficking is currently unknown. Both LMTK1 and LMTK2 interact with p35, an activa- 
tion subunit of cyclin-dependent kinase 5 (Cdk5), and are phosphorylated by Cdk5-p35 (Honma et al., 2003; Kesavapany et al., 2003; Tsutsumi et al., 2010). Cdk5 is a neuronal Ser/Thr protein kinase, and the Cdk5-p35 complex has critical roles in normal brain development, regulation of neuronal migration, neurite outgrowth, and membrane trafficking (Paglini et al., 2001; Hawasli and Bibb, 2007). Cdk5 has also been implicated in regulation of dopamine neurotransmission via phosphorylation of a key modulator in dopamine signaling, dopamine, and cAMP-regulated phosphoprotein (DARPP-32) (Bibb et al., 1999). Notably, recent studies have reported that mice lacking p35 display a hyperactive phenotype (Drerup et al., 2010; Krapacher et al., 2010), concomitant with an increase in striatal tyrosine hydroxylase (Krapacher et al., 2010), and a decrease in the basal threonine-34 (T34) phosphorylation level of DARPP-32 (Drerup et al., 2010). It is tempting to speculate that, like LMTK1 and LMTK2, LMTK3 acts as a downstream effector of Cdk5-p35, contributing to modulation of locomotor activity in mice. However, no significant alterations were observed between WT and Lmtk $3^{-1-}$ mice for tyrosine hydroxylase protein levels or in the phosphorylation status of T34 of DARPP-32 in the striatum (data not shown). Although the detailed spatiotemporal modulation of phosphorylation states of those molecules should be carefully examined, these results suggest that LMTK3 does not act in the Cdk5-p35-mediated signaling pathway within the context of its direct involvement in control of the tyrosine hydroxylase level and/or the phosphorylation status of DARPP-32.

Important clues for clarifying the cause of behavioral abnormalities in $L m t k 3^{-1-}$ mice are the findings that LMTK3 is enriched in the PSD fraction, is present in endocytic vesicles together with AP-2, and is involved in NMDAR endocytic trafficking in neurons. The glutamate and dopamine pathways interact extensively within various brain regions to regulate physiological functions, such as locomotor activity and memory processes (Adriani et al., 1998). Concurrent alterations of the glutamate and dopamine pathways are implicated in the pathophysiology of neurological diseases, including schizophrenia and Parkinson's disease (Surmeier et al., 2007). Several studies also support an essential role of NMDAR in motor and cognitive functions using mice with modifications of genes encoding NMDAR subunits (Mohn et al., 1999). Furthermore, dysfunctions of NMDAR trafficking can contribute to neuropsychiatric phenotypes associated with Alzheimer's disease and schizophrenia (Lau and Zukin, 2007). Thus, dysregulation of NMDAR trafficking in $L m t k 3^{-1-}$ mice may well affect their locomotor activity. Surface NMDARs are targeted for clathrin-mediated endocytosis through interactions with the AP-2 adaptor complex at perisynaptic regions (Roche et al., 2001). NMDAR internalization is regulated through association with scaffolding proteins, such as PSD-95, in a phosphorylation-dependent manner, and NMDARs not bound to these proteins are readily internalized (Lin et al., 2004). Intriguingly, PSD-95 becomes hyperubiquitinated by the reduction of Cdk5-p35, and PSD-95 ubiquitination correlates with increased interaction with $\beta$-adaptin, a subunit of the AP-2 adaptor (Bianchetta et al., 2011). As LMTK3 could be a downstream effector of Cdk5-p35, loss of LMTK3 might affect clathrin-mediated internalization of NMDAR, where PSD-95 plays a part. Contrarily, Cdk5 is reported to be positively involved in GluN2B/NMDAR endocytosis (Zhang et al., 2008). It is interesting to speculate that LMTK3 is an effector of Cdk5 and plays a part as a negative regulator for internalization of surface receptors, such as NMDAR in neurons. Further investigation of the normal roles of LMTK3 is essential to assess the speculation.

\section{References}

Adriani W, Felici A, Sargolini F, Roullet P, Usiello A, Oliverio A, Mele A (1998) N-Methyl-D-aspartate and dopamine receptor involvement in the modulation of locomotor activity and memory processes. Exp Brain Res 123:52-59. CrossRef Medline

Arias-Carrion O, Poppel E (2007) Dopamine, learning, and reward-seeking behavior. Acta Neurobiol Exp (Wars) 67:481-488. Medline

Bianchetta MJ, Lam TT, Jones SN, Morabito MA (2011) Cyclin-dependent kinase 5 regulates PSD-95 ubiquitination in neurons. J Neurosci 31: 12029-12035. CrossRef Medline

Bibb JA, Snyder GL, Nishi A, Yan Z, Meijer L, Fienberg AA, Tsai LH, Kwon YT, Girault JA, Czernik AJ, Huganir RL, Hemmings HC Jr, Nairn AC, Greengard P (1999) Phosphorylation of DARPP-32 by Cdk5 modulates dopamine signalling in neurons. Nature 402:669-671. CrossRef Medline

Bongsebandhu-phubhakdi S, Manabe T (2007) The neuropeptide nociceptin is a synaptically released endogenous inhibitor of hippocampal longterm potentiation. J Neurosci 27:4850-4858. CrossRef Medline

Chibalina MV, Seaman MN, Miller CC, Kendrick-Jones J, Buss F (2007) Myosin VI and its interacting protein LMTK2 regulate tubule formation and transport to the endocytic recycling compartment. J Cell Sci 120: 4278-4288. CrossRef Medline

Drerup JM, Hayashi K, Cui H, Mettlach GL, Long MA, Marvin M, Sun X, Goldberg MS, Lutter M, Bibb JA (2010) Attention-deficit/hyperactivity phenotype in mice lacking the cyclin-dependent kinase 5 cofactor $\mathrm{p} 35$. Biol Psychiatry 68:1163-1171. CrossRef Medline

Gainetdinov RR, Wetsel WC, Jones SR, Levin ED, Jaber M, Caron MG (1999) Role of serotonin in the paradoxical calming effect of psychostimulants on hyperactivity. Science 283:397-401. CrossRef Medline

Hawasli AH, Bibb JA (2007) Alternative roles for Cdk5 in learning and synaptic plasticity. Biotechnol J 2:941-948. CrossRef Medline

Honma N, Asada A, Takeshita S, Enomoto M, Yamakawa E, Tsutsumi K, Saito T, Satoh T, Itoh H, Kaziro Y, Kishimoto T, Hisanaga S (2003) Apoptosis-associated tyrosine kinase is a Cdk 5 activator $\mathrm{p} 35$ binding protein. Biochem Biophys Res Commun 310:398-404. CrossRef Medline

Inoue T, Kon T, Ohkura R, Yamakawa H, Ohara O, Yokota J, Sutoh K (2008) BREK/LMTK2 is a myosin VI-binding protein involved in endosomal membrane trafficking. Genes Cells 13:483-495. CrossRef Medline

Kawa S, Fujimoto J, Tezuka T, Nakazawa T, Yamamoto T (2004) Involvement of BREK, a serine/threonine kinase enriched in brain, in NGF signalling. Genes Cells 9:219-232. CrossRef Medline

Kawa S, Ito C, Toyama Y, Maekawa M, Tezuka T, Nakamura T, Nakazawa T, Yokoyama K, Yoshida N, Toshimori K, Yamamoto T (2006) Azoospermia in mice with targeted disruption of the Brek/Lmtk2 (brain-enriched kinase/lemur tyrosine kinase 2) gene. Proc Natl Acad Sci U S A 103: 19344-19349. CrossRef Medline

Kesavapany S, Lau KF, Ackerley S, Banner SJ, Shemilt SJ, Cooper JD, Leigh PN, Shaw CE, McLoughlin DM, Miller CC (2003) Identification of a novel, membrane-associated neuronal kinase, cyclin-dependent kinase 5/p35-regulated kinase. J Neurosci 23:4975-4983. Medline

Koch M (1999) The neurobiology of startle. Prog Neurobiol 59:107-128. CrossRef Medline

Krapacher FA, Mlewski EC, Ferreras S, Pisano V, Paolorossi M, Hansen C, Paglini G (2010) Mice lacking p35 display hyperactivity and paradoxical response to psychostimulants. J Neurochem 114:203-214. CrossRef Medline

Lau CG, Zukin RS (2007) NMDA receptor trafficking in synaptic plasticity and neuropsychiatric disorders. Nat Rev Neurosci 8:413-426. CrossRef Medline

Lavezzari G, McCallum J, Dewey CM, Roche KW (2004) Subunit-specific regulation of NMDA receptor endocytosis. J Neurosci 24:6383-6391. CrossRef Medline

Lin Y, Skeberdis VA, Francesconi A, Bennett MV, Zukin RS (2004) Postsynaptic density protein-95 regulates NMDA channel gating and surface expression. J Neurosci 24:10138-10148. CrossRef Medline

Man HY, Lin JW, Ju WH, Ahmadian G, Liu L, Becker LE, Sheng M, Wang YT (2000) Regulation of AMPA receptor-mediated synaptic transmission by clathrin-dependent receptor internalization. Neuron 25:649-662. CrossRef Medline

Mohn AR, Gainetdinov RR, Caron MG, Koller BH (1999) Mice with reduced NMDA receptor expression display behaviors related to schizophrenia. Cell 98:427-436. CrossRef Medline

Nakazawa T, Komai S, Tezuka T, Hisatsune C, Umemori H, Semba K, 
Mishina M, Manabe T, Yamamoto T (2001) Characterization of Fynmediated tyrosine phosphorylation sites on GluR epsilon 2 (NR2B) subunit of the N-methyl-D-aspartate receptor. J Biol Chem 276:693-699. CrossRef Medline

Nakazawa T, Komai S, Watabe AM, Kiyama Y, Fukaya M, Arima-Yoshida F, Horai R, Sudo K, Ebine K, Delawary M, Goto J, Umemori H, Tezuka T, Iwakura Y, Watanabe M, Yamamoto T, Manabe T (2006) NR2B tyrosine phosphorylation modulates fear learning as well as amygdaloid synaptic plasticity. EMBO J 25:2867-2877. CrossRef Medline

Nakazawa T, Kuriu T, Tezuka T, Umemori H, Okabe S, Yamamoto T (2008) Regulation of dendritic spine morphology by an NMDA receptorassociated Rho GTPase-activating protein, p250GAP. J Neurochem 105: 1384-1393. CrossRef Medline

Paglini G, Peris L, Diez-Guerra J, Quiroga S, Cáceres A (2001) The Cdk5p35 kinase associates with the Golgi apparatus and regulates membrane traffic. EMBO Rep 2:1139-1144. CrossRef Medline

Pogorelov VM, Rodriguiz RM, Insco ML, Caron MG, Wetsel WC (2005) Novelty seeking and stereotypic activation of behavior in mice with disruption of the Datl gene. Neuropsychopharmacology 30:1818-1831. CrossRef Medline

Ralph-Williams RJ, Paulus MP, Zhuang X, Hen R, Geyer MA (2003) Valproate attenuates hyperactive and perseverative behaviors in mutant mice with a dysregulated dopamine system. Biol Psychiatry 53:352-359. CrossRef Medline

Roche KW, Standley S, McCallum J, Dune Ly C, Ehlers MD, Wenthold RJ (2001) Molecular determinants of NMDA receptor internalization. Nat Neurosci 4:794-802. CrossRef Medline

Russell VA (2011) Overview of animal models of attention deficit hyperactivity disorder (ADHD). Curr Protoc Neurosci Chapter 9:Unit9 35. CrossRef Medline

Russell VA, Sagvolden T, Johansen EB (2005) Animal models of attentiondeficit hyperactivity disorder. Behav Brain Funct 1:9. CrossRef Medline

Sans N, Petralia RS, Wang YX, Blahos J 2nd, Hell JW, Wenthold RJ (2000) A developmental change in NMDA receptor-associated proteins at hippocampal synapses. J Neurosci 20:1260-1271. Medline

Sheng M, Cummings J, Roldan LA, Jan YN, Jan LY (1994) Changing subunit composition of heteromeric NMDA receptors during development of rat cortex. Nature 368:144-147. CrossRef Medline

Steiner H, Fuchs S, Accili D (1997) D3 dopamine receptor-deficient mouse: evidence for reduced anxiety. Physiol Behav 63:137-141. CrossRef Medline

Surmeier DJ, Ding J, Day M, Wang Z, Shen W (2007) D1 and D2 dopaminereceptor modulation of striatal glutamatergic signaling in striatal medium spiny neurons. Trends Neurosci 30:228-235. CrossRef Medline
Sztul E, Kaplin A, Saucan L, Palade G (1991) Protein traffic between distinct plasma membrane domains: isolation and characterization of vesicular carriers involved in transcytosis. Cell 64:81-89. CrossRef Medline

Takano T, Tsutsumi K, Saito T, Asada A, Tomomura M, Fukuda M, Hisanaga S (2010) AATYK1A phosphorylation by Cdk5 regulates the recycling endosome pathway. Genes Cells 15:783-797. CrossRef Medline

Takeuchi T, Kiyama Y, Nakamura K, Tsujita M, Matsuda I, Mori H, Munemoto Y, Kuriyama H, Natsume R, Sakimura K, Mishina M (2001) Roles of the glutamate receptor epsilon 2 and $\delta 2$ subunits in the potentiation and prepulse inhibition of the acoustic startle reflex. Eur J Neurosci 14:153-160. CrossRef Medline

Tang TT, Badger JD 2nd, Roche PA, Roche KW (2010) Novel approach to probe subunit-specific contributions to $N$-methyl-D-aspartate (NMDA) receptor trafficking reveals a dominant role for NR2B in receptor recycling. J Biol Chem 285:20975-20981. CrossRef Medline

Taniguchi S, Nakazawa T, Tanimura A, Kiyama Y, Tezuka T, Watabe AM, Katayama N, Yokoyama K, Inoue T, Izumi-Nakaseko H, Kakuta S, Sudo K, Iwakura Y, Umemori H, Inoue T,Murphy NP, Hashimoto K, Kano M, Manabe T, Yamamoto T (2009) Involvement of NMDAR2A tyrosine phosphorylation in depression-related behaviour. EMBO J 28:37173729. CrossRef Medline

Tomomura M, Morita N, Yoshikawa F, Konishi A, Akiyama H, Furuichi T, Kamiguchi H (2007) Structural and functional analysis of the apoptosisassociated tyrosine kinase (AATYK) family. Neuroscience 148:510-521. CrossRef Medline

Tsutsumi K, Takano T, Endo R, Fukuda M, Ohshima T, Tomomura M, Hisanaga S (2010) Phosphorylation of AATYK1 by Cdk5 suppresses its tyrosine phosphorylation. PLoS One 5:e10260. CrossRef Medline

Wultz B, Sagvolden T, Moser EI, Moser MB (1990) The spontaneously hypertensive rat as an animal model of attention-deficit hyperactivity disorder: effects of methylphenidate on exploratory behavior. Behav Neural Biol 53:88-102. CrossRef Medline

Yagi T, Tokunaga T, Furuta Y, Nada S, Yoshida M, Tsukada T, Saga Y, Takeda N, Ikawa Y, Aizawa S (1993) A novel ES cell line, TT2, with high germline-differentiating potency. Anal Biochem 214:70-76. CrossRef Medline

Yao WD, Spealman RD, Zhang J (2008) Dopaminergic signaling in dendritic spines. Biochem Pharmacol 75:2055-2069. CrossRef Medline

Zhang J, Forkstam C, Engel JA, Svensson L (2000) Role of dopamine in prepulse inhibition of acoustic startle. Psychopharmacology (Berl) 149: 181-188. CrossRef Medline

Zhang S, Edelmann L, Liu J, Crandall JE, Morabito MA (2008) Cdk5 regulates the phosphorylation of tyrosine 1472 NR2B and the surface expression of NMDA receptors. J Neurosci 28:415-424. CrossRef Medline 